\title{
The avian cell line AGE1.CR.pIX characterized by metabolic flux analysis
}

\author{
Verena Lohr ${ }^{1,2^{*}}{ }$, Oliver Hädicke ${ }^{1 \dagger}$, Yvonne Genzel $^{1}$, Ingo Jordan², Heino Büntemeyer ${ }^{3}$, Steffen Klamt ${ }^{1}$ \\ and Udo Reichl ${ }^{1,4}$
}

\begin{abstract}
Background: In human vaccine manufacturing some pathogens such as Modified Vaccinia Virus Ankara, measles, mumps virus as well as influenza viruses are still produced on primary material derived from embryonated chicken eggs. Processes depending on primary cell culture, however, are difficult to adapt to modern vaccine production. Therefore, we derived previously a continuous suspension cell line, AGE1.CR.pIX, from muscovy duck and established chemically-defined media for virus propagation.
\end{abstract}

Results: To better understand vaccine production processes, we developed a stoichiometric model of the central metabolism of AGE1.CR.pIX cells and applied flux variability and metabolic flux analysis. Results were compared to literature dealing with mammalian and insect cell culture metabolism focusing on the question whether cultured avian cells differ in metabolism. Qualitatively, the observed flux distribution of this avian cell line was similar to distributions found for mammalian cell lines (e.g. CHO, MDCK cells). In particular, glucose was catabolized inefficiently and glycolysis and TCA cycle seem to be only weakly connected.

Conclusions: A distinguishing feature of the avian cell line is that glutaminolysis plays only a minor role in energy generation and production of precursors, resulting in low extracellular ammonia concentrations. This metabolic flux study is the first for a continuous avian cell line. It provides a basis for further metabolic analyses to exploit the biotechnological potential of avian and vertebrate cell lines and to develop specific optimized cell culture processes, e.g. vaccine production processes.

Keywords: Avian cell line AGE1.CR.pIX, Biomass composition, Flux variability analysis, Metabolic network modeling, Glutaminolysis

\section{Background}

Novel therapeutic options have been made possible with production of animal cell culture-derived biopharmaceuticals. An enormous amount of insight has been published on production of recombinant proteins (including antibodies) since the first products have been licensed for application in humans 1986 and 1987. CHO cells are the main substrate for recombinant proteins and therefore most metabolic studies describe these cells [1,2]. Regarding vaccine manufacturing, literature on properties and metabolism of host cells during growth and virus

\footnotetext{
* Correspondence: verena.lohr@probiogen.de

${ }^{\dagger}$ Equal contributors

'Max Planck Institute for Dynamics of Complex Technical Systems, Sandtorstr. 1, 39106 Magdeburg, Germany

${ }^{2}$ Current address: ProBioGen AG, Goethestr. 54, 13086 Berlin, Germany

Full list of author information is available at the end of the article
}

replication as well as process design and optimization is less abundant and not as focused. One reason is that safety considerations and execution of pre-clinical and clinical trials are paramount for vaccines because this medication usually is administered to healthy recipients. Another reason is the multitude of process options and host cell systems used for propagation of pathogens. For historic reasons, primary cultures (today usually embryonated chicken eggs or chicken embryo fibroblasts), diploid cell strains (human embryonic WI-38 and MRC-5), and few continuous cell lines (i.e. macaque-derived Vero cells or MDCK cells) are associated with the lowest possible risks to the vaccine recipients. Production with such cellular substrates often is performed in the presence of calf serum and adherent culture with little room for optimization. Furthermore, standardization of experiments is difficult with primary chicken material. 
Several virus strains and viral vectors, e.g. Modified Vaccinia Virus Ankara (MVA), only replicate efficiently in avian cells [3]. Accordingly, primary chicken fibroblasts are still a commonly accepted production substrate. As vectored vaccines are gaining increasing importance [4], the potential of continuous suspension cells that proliferate in chemically-defined media are attracting more and more attention. Therefore, continuous avian cell lines are being investigated as a viable option to replace primary material. One possible new cell candidate that meets these criteria is the avian designer cell line AGE1.CR.pIX (in the following: CR.pIX) that proliferates in fully scalable suspension culture and is adapted to growth in a chemicallydefined medium [5,6]. The latter property is an advantage for metabolic flux analysis as no unknown or complex components such as animal sera or hydrolysates that complicate carbon and nitrogen balance closure are present.

Metabolic models have been developed for a variety of cell lines to study physiological states or changes in metabolism as a response to different cultivation strategies, medium composition or stimuli like virus infection or accumulation of toxins. For example, the human cell lines HEK293 [7,8] and AGE1.HN [9,10], other mammalian cells like CHO [11], BHK [12], MDCK [13,14] and hybridoma cells $[15,16]$ or insect cell lines like Sf9 $[17,18]$ have been studied because of their relevance for the production of biopharmaceuticals. For all these cell lines, the two main pathways for energy generation and precursor supply were found to be glucose catabolism via glycolysis and glutamine catabolism via the TCA cycle, referred to as glutaminolysis [19-21]. Therefore, cell culture media usually contain substantial amounts of both substrates. Associated with an overflow metabolism based on glucose and a high glutaminolysis activity is the accumulation of lactate and ammonia in the cultivation broth with a negative impact on cell growth and product formation [22,23].

To describe cell metabolism, various mathematical methods have been developed and comprehensive reviews on applied approaches and their benefits for mammalian cell culture research are available [24,25]. Mass balancing techniques like metabolic flux analysis (MFA) can be performed for analysis of cellular growth, requiring only a comparatively small set of experimental data. During the exponential growth phase of batch cultivations or continuous cultivations this method can be used to evaluate possible intracellular flux distributions based on measurements of exchange fluxes. However, if the system is underdetermined, no unique flux distribution can be calculated. One approach to circumvent this limitation is to perform ${ }^{13} \mathrm{C}$ labelling experiments. The higher experimental effort of such studies comes with the advantage of an increased number of constraints and uniquely resolvable flux distributions [26]. Another possibility is to apply flux variability analysis (FVA), a method related to MFA that calculates a flux range instead of a distinct flux value [27]. The advantage of this method is that it is experimentally less demanding as it requires (as MFA) only extracellular metabolite and cell concentrations as well as the biomass composition. Intracellular flux ranges from measured extracellular rates (uptake and release of metabolites) can then be computed with the help of software tools such as the CellNetAnalyzer toolbox [28].

As a starting point for studying metabolism of avian CR.pIX cells during growth, we developed a network model for the central metabolism oriented in size and scope on other published models of the central metabolism of mammalian and insect cell lines (see Figure 1). Pathways were selected based on entries from avian species in the Kyoto Encyclopedia of Genes and Genomes (KEGG) database. As it was not known whether biomass composition of avian cells is comparable to other examined cells, we first determined relative proportions of biomass components experimentally. FVA and MFA were then applied to assess the metabolic behaviour of CR.pIX cells during exponential growth in a $1 \mathrm{~L}$ stirred tank reactor (STR). Finally, to verify emerging hypotheses regarding metabolic pathways, especially glutaminolysis, enzyme activity measurements and additional growth experiments were performed.

\section{Results and discussion}

\section{Biomass composition}

To allow metabolic flux analysis, some cell characteristics need to be known, i.e. specific dry cell weight and biomass composition. As it was not known whether similar results to other eukaryotic cells could be expected for an avian cell, most characteristics were determined experimentally rather than presumed.

The specific cell dry weight of CR.pIX cells was measured with $314 \mathrm{pg} / \mathrm{cell}$. Amounts of DNA $(2.3 \pm 0.5 \%$ of biomass) and RNA (3.1 $\pm 0.2 \%)$ per CR.pIX cell were comparable to published values obtained for other eukaryotic cells. The protein content $(55.2 \pm 8.4 \%)$ was lower in CR. pIX cells than the typical range of $70-75 \%$ determined for other cells $[7,16,29]$. However, there are reports supporting a low protein content such as Zupke et al. who found $60 \%$ protein in mouse hybridoma cells and Carnicer et al. who measured a protein content of only $37 \%$ for yeast cells [30,31]. The relative amounts of amino acids of whole cell protein determined from CR.pIX cells are in general similar to published data on yeast [31], mammalian cells $[9,29,32]$ and insect cell lines [33] (see Additional file 1: Table S1). The remaining fraction of biomass was assigned to lipids and carbohydrates in a ratio of 1:2. The estimated lipid content $(13.1 \%)$ agrees with previous reports that vary between 9 and 20\%, whereas the assumed carbohydrate 


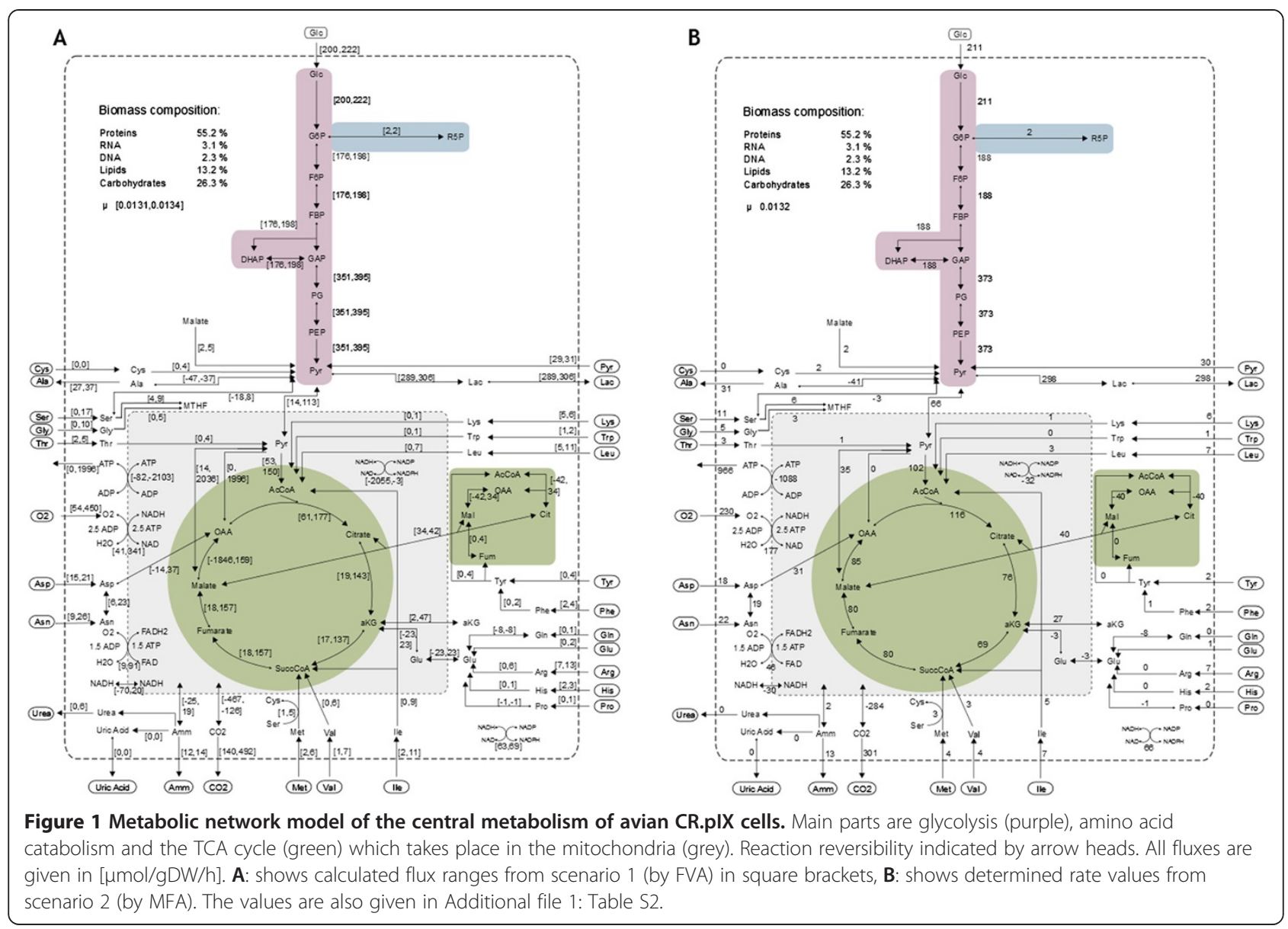

content $(26.3 \%)$ is at the upper limit of the wide range of $3.5-25.0 \%$ reported in literature $[7,16,29,30,34]$. However, a sensitivity analysis showed that absolute fractions of lipids and carbohydrates have only a minor impact on rate values of the calculated flux distributions (data not shown).

\section{Growth phases of CR.pIX cells in STR}

The growth of CR.pIX cells can be divided into distinct phases. First, an initial lag phase was observed lasting for about $24 \mathrm{~h}$ with only slightly increasing viable cell concentrations. Thereafter, cells grew exponentially until $172 \mathrm{~h}$. Following the exponential growth phase, a reduced growth was observed until 230 h, but viability was still above $90 \%$ in this intermediate growth phase (Figure 2A). After having reached the maximum viable cell concentration of $1.3 \times 10^{7}$ cells $/ \mathrm{mL}$, cell death started.

The region chosen for MFA and FVA was 24-97 $h$, where a growth rate of $0.0132 \mathrm{~h}^{-1}$ was observed. In the following, only this time frame is considered when describing and discussing extracellular rates and intracellular flux distributions as it is very likely that the quasi steady state assumption holds. Furthermore, it is also the typical time frame in which cells are grown before infection in virus production processes (MVA or influenza A and B virus) [6,35]. Studies in this time frame are therefore most relevant in terms of vaccine manufacturing using CR.pIX cells.

\section{Exchange rates from measured extracellular metabolites}

Determined exchange rates of CR.pIX were compared to rates given in other publications for mammalian cell lines (Table 1). We chose 6 data sets where equal units were given or could be calculated for comparison, thereof three publications on the metabolism of human AGE1.HN cells [9,10,36], one publication on HEK293 cells [7], and one on MDCK cells [13]. The majority of concentration profiles of CR.pIX cultivations are similar to concentration profiles obtained for other transformed cell lines studied in the past. For most of the metabolites, the measured exchange rates during CR.pIX cultivation have the same direction (uptake or release) and are in the same range compared to those found for other cell lines. Most notably, as observed for other cell lines, almost all of the consumed glucose is converted to lactate and excreted in the medium (Figure 2B). Key differences in the rates 


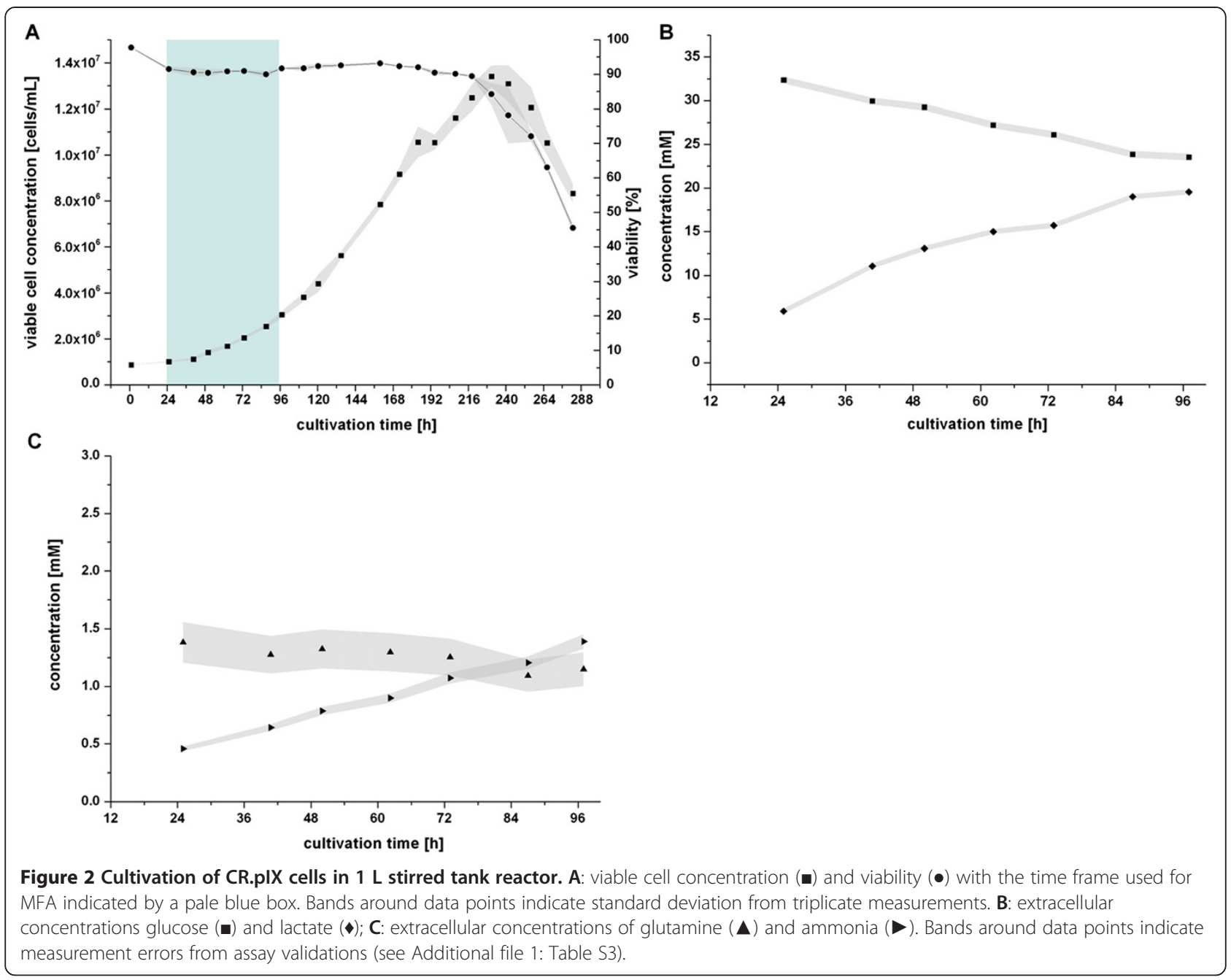

of CR.pIX cell cultivations were observed for the following metabolites:

First, glutamine uptake is zero with CR.pIX cells (Figure $2 \mathrm{C}$ ) as the observed glutamine concentration decrease is solely due to glutamine hydrolysis. Associated with this, only low amounts of ammonia accumulated in the medium (1.4 mM after $97 \mathrm{~h}$ : maximal $2.8 \mathrm{mM}$ at the end of the batch cultivation at $210 \mathrm{~h}$ ). For production of cell culture-derived products this is a beneficial characteristic as higher ammonia concentrations are known to be toxic with negative impact on cell growth and product formation [22]. The observed ammonia concentration is at the lower limit compared to other cells, where concentrations between 3 and $8 \mathrm{mM}$ were reported to lead to impaired growth [37-39].

The second difference is observable for glycine which is taken up by CR.pIX cells, but released by other cell lines. This observation can be explained by the fact that glycine is reported to be an essential amino acid for birds and therefore needs to be provided for CR.pIX cells by the medium [40]. The third finding is that aspartate and asparagine are consumed by CR.pIX cells in higher amounts or at least at higher rates compared to other cell lines. Both amino acids can be converted to oxaloacetate and thus channeled into the TCA cycle. One could hypothesize that CR.pIX cells compensate in that way for the negligible glutamine uptake to fill the TCA cycle intermediate pools. We also observed that the measured uptake rates for the essential amino acids histidine, lysine and tryptophan were slightly below their minimal requirements for biomass formation with the determined growth rate. For the following analyses we therefore adjusted their upper boundaries slightly to fit the minimal stoichiometric demands for the measured specific growth rate.

\section{Intracellular flux distribution}

Using a metabolic network model of the central metabolism of avian cells that we developed according to literature data and database entries, the metabolism of CR.pIX cells during cultivation in 1 L STR was studied using FVA (details see section "Flux variability and 
Table 1 Determined extracellular fluxes for cultivation of CR.pIX cells in comparison with literature data

\begin{tabular}{|c|c|c|c|c|c|c|}
\hline & CR.pIX STR & AGE1.hn Shaker ${ }^{a}$ & AGE1.hn Tube ${ }^{b}$ & AGE1.hn Tube ${ }^{c}$ & HEK293 STR ${ }^{d, f}$ & MDCK STR ${ }^{\mathrm{e}, \mathrm{f}}$ \\
\hline Time frame & 24-97 h & $18-90 \mathrm{~h}$ & $72-169 \mathrm{~h}$ & $0-74 \mathrm{~h}$ & $0-72 \mathrm{~h}$ & $16-80 \mathrm{~h}$ \\
\hline Initial glc conc. [mM] & 33 & $20-25$ & 30 & 30 & 15 & 30 \\
\hline Initial gln conc. [mM] & 1.5 & 5 & 2 & 4 & 1 & 2 \\
\hline Glc & $-211.2 \pm 10.8^{9}$ & -123.0 & -126.9 & -429.2 & -395.5 & -1108.7 \\
\hline Lac & $297.6 \pm 8.8$ & 263.3 & 87.6 & 639.8 & 439.0 & 2108.0 \\
\hline Pyr & $-30.1 \pm 0.8$ & -28.7 & -2.9 & -76.5 & - & 0.0 \\
\hline Gln & $-0.1 \pm 0.1$ & -37.1 & -41.2 & -95.5 & -66.5 & -70.9 \\
\hline $\mathrm{Amm}$ & $12.6 \pm 0.9$ & - & - & 91.7 & 48.5 & 51.8 \\
\hline Glu & $-1.4 \pm 1.1$ & 4.0 & 0.9 & 17.0 & -1.4 & -42.1 \\
\hline Ala & $31.6 \pm 4.9$ & 17.5 & 8.0 & 20.6 & 11.8 & -49.4 \\
\hline $\operatorname{Arg}$ & $-9.9 \pm 2.8$ & -8.2 & -4.4 & -12.4 & -15.3 & -11.7 \\
\hline Asn & $-17.1 \pm 8.5$ & -2.9 & -2.0 & -7.3 & -4.6 & -1.9 \\
\hline Asp & $-17.8 \pm 3.2$ & -14.1 & -8.9 & -16.2 & -0.2 & -2.0 \\
\hline Cys & 0.0 & 0.2 & -1.1 & -0.2 & - & -2.4 \\
\hline Gly & $-4.8 \pm 4.8$ & 2.6 & -0.8 & 6.8 & 17.0 & 2.3 \\
\hline His & $-2.3 \pm 0.4$ & -1.7 & -0.7 & -3.2 & -3.5 & -2.8 \\
\hline Ile & $-6.2 \pm 4.4$ & -8.1 & -1.4 & -14.7 & -21.8 & -12.3 \\
\hline Leu & $-7.9 \pm 3.2$ & -11.5 & -3.2 & -23.8 & -24.7 & -23.5 \\
\hline Lys & $-5.5 \pm 0.3$ & -6.9 & -3.5 & -16.6 & -12.6 & -22.9 \\
\hline Met & $-4.1 \pm 2.0$ & -3.1 & -1.2 & -6.6 & -4.9 & -6.4 \\
\hline Phe & $-2.5 \pm 1.0$ & -3.3 & -1.5 & -6.3 & -5.4 & -8.9 \\
\hline Pro & $-0.1 \pm 0.1$ & 7.1 & 13.1 & 13.4 & 0.8 & 6.7 \\
\hline Ser & $-8.3 \pm 8.3$ & -12.2 & -5.7 & -33.4 & -17.7 & -16.8 \\
\hline Thr & $-3.4 \pm 1.9$ & -4.9 & -2.0 & -8.0 & -9.5 & -14.9 \\
\hline Trp & $-1.5 \pm 0.2$ & -0.9 & -0.4 & -0.8 & - & -5.2 \\
\hline Tyr & $-1.8 \pm 1.8$ & -2.8 & -1.4 & -5.5 & -4.6 & -5.0 \\
\hline Val & $-4.3 \pm 2.8$ & -8.4 & -1.8 & -14.2 & -19.1 & -17.0 \\
\hline Uric acid & 0.0 & - & - & - & - & - \\
\hline
\end{tabular}

All rates are given in $\mu \mathrm{mol} / \mathrm{gDW} / \mathrm{h}$.

afrom [9]; ${ }^{b}$ from [36]; ' from [10]; ${ }^{\text {ffrom [7]; }}$ efrom [13,14].

these fluxes were re-calculated to $[\mu \mathrm{mol} / \mathrm{gDW} / \mathrm{h}]$ with the given fluxes and cell dry weights.

${ }^{9}$ standard deviation from Monte-Carlo sampling using validated standard deviations of the methods as boundaries.

metabolic flux analysis"). The time span of $24 \mathrm{~h}$ and $97 \mathrm{~h}$ was chosen for analysis, as within this time interval during exponential growth, the quasi steady state assumption holds. FVA uses as few constraints for the metabolic network as possible in order to get an unbiased look at the metabolism. This generated a distribution of flux ranges that is named scenario 1 in this manuscript. However, flux ranges are sometimes difficult to interpret. Therefore, after having performed FVA, we set few reasonable constraints, e.g. uptake and excretion rates were set as fixed and the pyruvate carboxylase activity was assumed to be inactive. With these constraints a unique flux distribution could be calculated which is discussed as scenario 2 in the following.
All calculated flux ranges (scenario 1; determined by FVA) and fluxes (for scenario 2, determined by MFA) are given in the Additional file (Additional file 1: Table S2). Together with the network, main fluxes are also depicted in Figure 1. Although only flux ranges can be calculated with the constraints of scenario 1 (Figure 1A), some conclusions can already be drawn from them as we will discuss below. However, most of the following discussion will refer to the unique flux distribution calculated for scenario 2 (Figure 1B). With the applied constraints, the linear equation system had two degrees of redundancy. Therefore, the sum of the variance weighted squared residuals (h) need to be below 5.99 to exclude significant measurement errors (with an applied significance level of $\alpha=0.05$ ). 
Since we obtained an $h$-value of 0.63 we concluded that the model fitted the data sufficiently well.

\section{Glycolysis and cytosolic pyruvate metabolism}

Glucose is taken up with a high rate $(211 \mu \mathrm{mol} / \mathrm{gDW} / \mathrm{h})$ and then processed via glycolytic reactions to pyruvate. Only $1 \%$ of the glucose is fed into the pentose phosphate pathway for nucleotide synthesis. Such low pentose phosphate influxes were also observed in other studies with transformed cells, e.g. $1.5 \%$ and $2.9 \%$ in human AGE1.HN cells $[9,36]$. The calculated ranges for the rates of glycolysis are relatively narrow as they mainly depend on the glucose uptake rate that was given by the measurement of extracellular glucose. Cytosolic pyruvate is mainly derived from glycolysis (92\%); the rest of the cytoplasmic pyruvate is taken up by the cells and in small parts obtained from cysteine degradation and the malic enzyme reaction (together 1\%). Similar to other transformed cells, cytosolic pyruvate is mainly converted to lactate $(73 \%)$ or alanine (10\%). Only a small fraction (16\%) is transported to the mitochondria where it is converted to acetyl-CoA and further oxidized. However, if a complete pentose phosphate pathway (PPP) is included in the model, the exact ratio between glycolysis and PPP is unresolvable and the corresponding flux ranges would be notably wider. Since $\mathrm{CO}_{2}$ is produced via the PPP, a high PPP flux would reduce the amount of carbon that re-enters the lower part of glycolysis, and therefore even less pyruvate would enter the TCA cycle.

In general, the flux distribution at the cytosolic pyruvate node shows that the majority of the glucose-associated metabolism of CR.pIX cells is used to generate ATP and reducing equivalents via glycolysis. The known Warburg effect of enhanced aerobic glycolysis, leading mostly to lactate, can thus also be observed in transformed cells from avian origin. Furthermore, there seems to be a weak coupling to the mitochondrial TCA cycle as only a minority of the cytosolic pyruvate is channeled into the mitochondria. Other studies have shown that several transformed cell lines show low activities of the three pyruvate dependent enzymes pyruvate dehydrogenase $(\mathrm{PDH})$, pyruvate decarboxylase (PC) and phosphoenolpyruvate carboxykinase (PEPCK) that can serve as connectors between glycolysis and TCA cycle [41,42]. For our cells, we calculated that the PDH (r33) must carry some flux (since the lower boundary of this reaction is strictly positive), but the non-resolvable $\mathrm{PC}$ reaction (r46) is not obligatory as its flux range also includes zero. Measurements on activities of anaplerotic enzymes will be discussed in a later subsection.

\section{Mitochondrial pyruvate metabolism and TCA cycle}

The mitochondrial pyruvate pool is fed from the cytosolic pyruvate pool (64\%) and the anaplerotic malate conversion (34\%). $100 \%$ of the efflux is catalyzed by the pyruvate dehydrogenase thereby generating $88 \%$ of the mitochondrial acetyl-CoA. Other influxes towards this TCA precursor come from amino acids, namely isoleucine (4\%) and leucine (7\%), tryptophan, and lysine (together $1 \%)$. The subsequent reactions of the TCA cycle are fed from other catabolic reactions: $\alpha$-ketoglutarate from cytosolic influx and succinyl-CoA from isoleucine, valine, serine and methionine degradation. This shows the dependency of the TCA cycle activity on relatively high amino acid uptake and catabolic rates in CR.pIX cells.

\section{Oxidative phosphorylation \& ATP balance}

We calculated high fluxes for the oxidation of $\mathrm{NADH}$ $(177 \mu \mathrm{mol} / \mathrm{gDW} / \mathrm{h})$ and $\mathrm{FADH}_{2}(46 \mu \mathrm{mol} / \mathrm{gDW} / \mathrm{h})$. Since a transport reaction for NADH between the cytosol and mitochondria was included in the model, the pools of reducing equivalents for both compartments are balanced simultaneously. A minor flux for the corresponding transport reaction shifting reducing equivalents from the mitochondria to the cytosol was calculated with $30 \mu \mathrm{mol} /$ $\mathrm{gDW} / \mathrm{h}$. By setting this transport reaction to zero, cytosolic and mitochondrial reducing equivalents have to be balanced separately. Besides an increased oxygen uptake and ATP synthesis rate, this leads to no significant differences in the flux distributions (data not shown).

ATP generation via the TCA cycle and the electron transport chain makes up to $74 \%$ of the total ATP generated. A smaller fraction (26\%) is derived from glycolysis. This is similar to results from studies on mouse hybridoma and CHO cells $[43,44]$ where values of $60-80 \%$ of ATP production via the TCA cycle have been reported. Although considerable ATP amounts are needed for lipid synthesis, amino acid transporters, upper glycolysis and biomass, the high (unspecific) ATP consumption through reaction $\mathrm{r} 77(966 \mu \mathrm{mol} / \mathrm{gDW} / \mathrm{h})$ indicates that there seems to be an overload with ATP which is either used for certain maintenance processes or passed through futile cycles.

\section{Amino acid and nitrogen metabolism}

Degradation rates of some amino acids, e.g. tryptophan and histidine, are low, indicating that these amino acids are taken up to match the anabolic demand for synthesizing biomass rather than to further metabolize them via catabolic routes. The calculated rate ranges for most fluxes of the amino acid catabolism are constrained to relatively small intervals (e.g. for degradation of valine and histidine). There is no uric acid synthesis (r68) as no uric acid could be measured experimentally. Although this reaction is known to take place in avian cells, this is not a fully unexpected finding. Uric acid was detected in livers and kidneys of chicken and turkey, but not in all bird tissues [40]. CR.pIX cells, as other transformed cells, use ammonia as a sink and release the excess cytosolic ammonia (that is 
produced by deamination reactions of amino acids) into the medium where it accumulates. However, due to low glutamine exploitation, the ammonium concentration stays at a low level so that toxic concentrations are not reached.

Interestingly, the fluxes through the glutamine synthetase (r48) (i.e. in the direction of glutamate synthesis) are negative as glutamine uptake was not sufficient for biomass synthesis and glutamine therefore has to be synthesized from the glutamate pool. Glutamate itself is likely to be mainly derived from degradation reactions of isoleucine, valine and aspartate. Especially aspartate is taken up in large parts $(18 \mu \mathrm{mol} / \mathrm{gDW} / \mathrm{h})$ and can be converted to glutamate. Other amino acids that could compensate for glutamine conversion to glutamate are arginine, histidine and proline. However, only arginine is taken up in considerable amounts by the cells so that one could speculate that the path from glutamate to $\alpha$ ketoglutarate is generally not used extensively by the CR. pIX cells and thus, the classical dependency on glutamine is not given for CR.pIX cells. To elucidate unambiguously the source of carbon for glutamate synthesis, ${ }^{13} \mathrm{C}$ labelling experiments would be required, which are beyond the scope of the current contribution.

\section{In vitro enzyme activities}

To validate the two hypotheses from the previous section that i) glycolysis is only weakly connected to the TCA, and that ii) glutaminolysis plays a minor role in energy supply and precursor generation, we measured the maximum in vitro enzyme activities of the related enzymes.

For the first hypothesis, we measured maximum activities of PC and PDH. For both reactions, low enzyme activities of $0.2 \mathrm{nmol} / 10^{6} \mathrm{cells} / \mathrm{min}$ (i.e. $39 \mu \mathrm{mol} / \mathrm{gDW} / \mathrm{h}$ ) were measured as for MDCK cells [45]. These values supported the applied constraint of a missing carboxylating anaplerotic reaction from pyruvate towards oxaloacetate. However, the measured low PDH activity seems to contradict the calculated flux of $102 \mu \mathrm{mol} / \mathrm{gDW} / \mathrm{h}$. One possible explanation is given by the significantly smaller calculated lower boundary of this flux when applying fewer and less stringent assumptions with scenario 1 . However, at least a basal activity is required as the lower boundary is strictly positive $(53 \mu \mathrm{mol} / \mathrm{gDW} / \mathrm{h})$.

The second hypothesis, stating that glutaminolysis is inversed, was validated via measurements of glutaminase (converting glutamine to glutamate) and glutamine synthetase (converting glutamate to glutamine). Glutaminase showed a maximal activity of $0.1 \mathrm{nmol} / 10^{6}$ cells $/ \mathrm{min}$ (i.e. $19 \mu \mathrm{mol} / \mathrm{gDW} / \mathrm{h}$ ), which is an even lower value than the measured $1.5-7.4 \mathrm{nmol} / 10^{6} \mathrm{cells} / \mathrm{min}$ for MDCK cells $[45,46]$. The flux from glutamate to glutamine was predicted by flux analysis to be active towards glutamine in order to account for the unmet demand of glutamine for biomass formation. The measured enzyme activity of the catalyzing enzyme glutamine synthetase showed a maximal activity of $5.9 \mathrm{nmol} / 10^{6}$ cells/min (i.e. $1135 \mu \mathrm{mol} /$ $\mathrm{gDW} / \mathrm{h}$ ). This value is on the one hand significantly higher than the value for the reverse reaction and on the other hand at the upper limit of reported values for MDCK cells $\left(0.6-6.5 \mathrm{nmol} / 10^{6}\right.$ cells/min, $\left.[45,46]\right)$. Thus, although values from in vitro enzyme activity measurement and flux analysis are not directly convertible, the measured enzyme activities support the calculated flux distribution towards glutamine and the low level of glutamine usage.

\section{Growth in glutamine-free medium}

Since the uptake flux for glutamine was calculated as zero and the enzyme measurements supported the low glutaminolytic activity, we speculated whether glutamine is even dispensable for growth of CR.pIX cells. To validate this hypothesis, we performed shaker flask cultivations of CR.pIX cells in CD-U2 medium with $2 \mathrm{mM}$ glutamine and in CD-U2 medium without glutamine addition. As no serum is present in the medium, other glutamine sources can be excluded. Cultures with or without glutamine were run in parallel over 5 passages. For passage 5, a growth curve was recorded. Figure 3 shows that cells without glutamine did not grow as well as in the presence of glutamine during the first three passages (Figure 3A). Viability also dropped below 90\% in these cultures (Figure 3B). After passage 3, cell growth performance in glutamine-free medium increased significantly. Finally, cells in the $5^{\text {th }}$ passage in glutaminefree medium did grow comparably fast as in the presence of glutamine. Maximal viable cell concentrations of $1.4 \times 10^{7}$ cells $/ \mathrm{mL}$ were achieved with viabilities above 90\%. This experiment demonstrated that CR.pIX cells are capable of glutamine-independent growth. With $\mathrm{CHO}$ cells, this was achieved after several selection rounds [47], but could not be achieved with other cells $[48,49]$. Considering that we did not measure glutamine uptake fluxes, we were surprised at the intermittent decrease in proliferation rates and viabilities of CR.pIX cultures after glutamine removal. However, extracellular and intracellular glutamine mediate also non-nutritional effects that can impact apoptosis and heat shock responses $[50,51]$. We hypothesize that the short adaptation period after glutamine removal may be due to shifts in glutamine-responsive signaling pathways. Infection experiments with poxvirus MVA showed that productivity of CR.pIX cells is not negatively affected by glutamine absence (data not shown). The feature of glutamine-free growth of CR.pIX cells may be advantageous in particular for high cell density cultivations were ammonia accumulates to very high concentrations in the culture supernatant and prevents further increases in cell numbers and productivity $[38,52]$. 


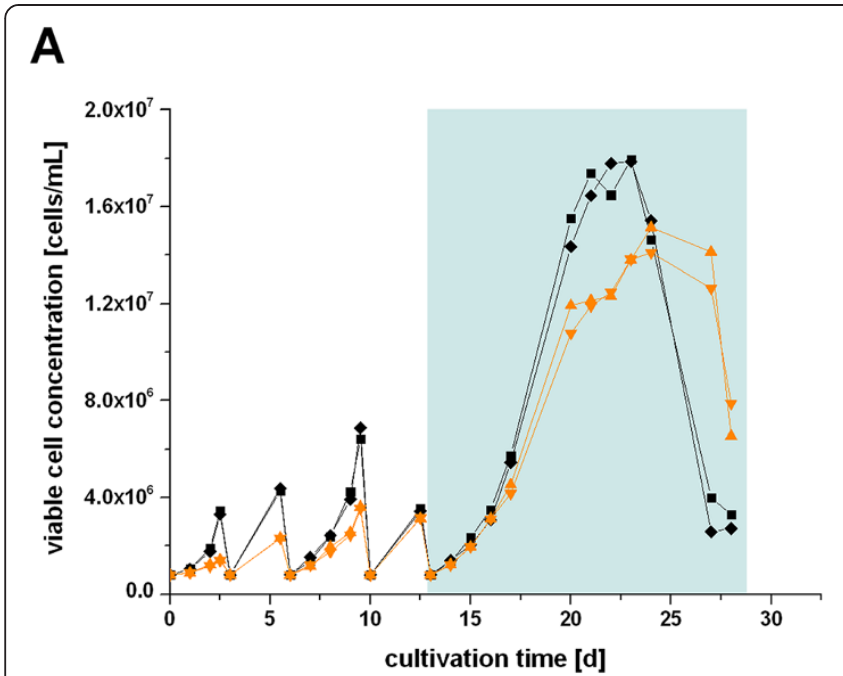

B

Figure 3 Cultivation of CR.pIX cells with (black squares) or without glutamine (orange triangles) in shaker flasks (two parallel cultures each). Viable cell concentrations (A) and viabilities (B) are shown for 5 subsequent passages of CR.plX cells in the respective medium. The pale blue box highlights the $5^{\text {th }}$ passage for which a growth curve was monitored.

\section{Conclusions}

Avian cells are important substrates for producing a number of licensed vaccines and various viral vector-based processes under development. The only avian substrates that are currently approved for production are embryonated chicken eggs or primary chicken embryo fibroblasts. Because processes using primary cultures are difficult to optimize and standardize, access to well characterized continuous avian cell lines, such as the CR.pIX cell line derived from a muscovy duck embryo, would be a significant step forward.

Here, we determined metabolic properties of the CR.pIX cell line to complement previous developments on scalable vaccine production processes in chemically defined media. The current study comprised three parts: i) analysis of biomass composition and measurements of cell and extracellular metabolite concentrations, ii) construction of a stoichiometric network for the central metabolism of avian cells and subsequent analysis with flux variability and metabolic flux analysis, and iii) experiments and analytics to validate hypotheses derived from the stoichiometric analysis.

The first part expands the available data base on the metabolism of immortalized cell lines. Results on biomass composition and growth properties of the avian CR.pIX cell line agree with data determined for other transformed mammalian and insect cell lines used in biopharmaceutical production.

Flux variability and metabolic flux analyses in the second part reveal an overflow metabolism similar to mammalian cells with high uptake of glucose followed by conversion to and release of lactate and alanine. The TCA cycle was only weakly connected to glycolysis and appeared to depend on the influx of amino acids, mainly isoleucine, valine and aspartate. Finally, our measurements together with flux (variability) analysis indicated that glutamine supplementation is not an essential requirement for CR.pIX cell proliferation.

The derived hypothesis on low glutaminolysis activity could be confirmed by enzyme activity measurements. However, the hypothesis of a weak connection between the cytosolic and mitochondrial pyruvate pools could not be confirmed entirely. To elucidate whether cytosolic pyruvate is transported in significant amounts from the cytosol to the mitochondria, e.g. ${ }^{13} \mathrm{C}$ labelling experiments could be helpful, which was beyond the scope of the current contribution. Low dependence on glutamine was confirmed by passaging cells in glutamine-free medium and agrees well with the observation that ammonia is accumulating to very low concentrations in the medium. This is a very beneficial property of CR.pIX cells especially for fed-batch cultivation strategies where ammonia often accumulates to toxic levels.

Overall, the present study provides a basis for a more focused metabolic analysis of avian cell lines and thus helps to further optimize medium and feed requirements. Acute infection and associated take-over of the metabolism by a virus may shift the requirements for certain nutrients. The derived model may therefore also provide a context for future studies on the metabolism of CR.pIX cells during the virus replication phase.

\section{Methods}

\section{Cell cultivations}

CR.pIX suspension cells were routinely cultivated in $250 \mathrm{~mL}$ shaker flasks (working volume $150 \mathrm{~mL}$, with 
membrane cap for aeration) in a chemically-defined medium (CD-U2, PAA) supplemented with glutamine (2 mM final concentration, Sigma), alanine (2 mM final concentration, Sigma) and a recombinant insulin-like growth factor (Long-R3 IGF, $10 \mathrm{ng} / \mathrm{mL}$ final concentration, Sigma). Flasks were incubated at $185 \mathrm{rpm}$ with $5 \mathrm{~cm}$ amplitude, $37^{\circ} \mathrm{C}$ and $5 \% \mathrm{CO}_{2}$. Pre-cultures for bioreactor experiments, cultures for determination of biomass composition as well as the comparative cultivations in glutamine-containing and glutamine-free medium were performed in shaker flasks. For inoculation of a $1 \mathrm{~L}$ stirred tank bioreactor (STR, DasGip AG, vessel: Spinner Type BS, cellferm-pro ${ }^{\circ}$ system), $8 \times 10^{5}$ cells $/ \mathrm{mL}$ in $1 \mathrm{~L}$ CD-U2 medium were transferred into the bioreactor. The bioreactor was equipped with a pitched-blade stirrer that was operated at $120 \mathrm{rpm}$. The temperature was controlled at $37^{\circ} \mathrm{C} ; \mathrm{pO}_{2}$ was set to $50 \%$ by pulsed aeration with air enriched with variable contents of $\mathrm{O}_{2}$ and $\mathrm{CO}_{2}$. During the first $60 \mathrm{~h}, \mathrm{pH}$ was slowly reduced from 7.4 (initial value of the medium) to 7.0 and controlled at this value subsequently by addition of $\mathrm{CO}_{2}$ or $1 \mathrm{M} \mathrm{Na}_{2} \mathrm{CO}_{3}$.

\section{Measurement of biomass composition}

All assays and analytics were performed with cells in the exponential growth phase. Therefore, samples were taken from shaker flask cultures at $72 \mathrm{~h}$ post inoculation. For each analysis, 3 biological replicates were measured with at least 3 technical replicates each.

For determination of dry cell weight, cell suspension containing about $1 \times 10^{8}$ cells $/ \mathrm{mL}$ was centrifuged $(500 \times \mathrm{g}$, $10 \mathrm{~min}$ ) and re-suspended in $10 \mathrm{~mL}$ of fresh medium. Samples were dried at $60^{\circ} \mathrm{C}$ until weight remained constant. The specific dry cell weight was calculated against weight of empty tubes and against a medium control (10 $\mathrm{mL}$ of fresh medium dried in tubes).

The BCA assay (Pierce/ThermoScientific) was used to determine the cellular protein content. Samples containing $4 \times 10^{6}$ cells were centrifuged $(500 \times \mathrm{g}, 10 \mathrm{~min})$ and resuspended in $1 \mathrm{~mL}$ lysis buffer (from CytoTox $96^{\circ}$ NonRadioactive Cytotoxicity Assay, Promega). After 15 min incubation at room temperature, samples were sonicated for $3 \mathrm{~min}$ in a water bath. Standard curves were prepared using BSA and analyzed together with samples by measuring the absorption at $562 \mathrm{~nm}$ (inifinite200 plate reader, TecanGroup).

For DNA purification, a culture volume containing $5 \times 10^{6}$ cells was taken and purified with the QIAamp DNA Blood Mini kit (Qiagen) according to the procedure "protocol for cultured cells". After purification, $2 \mu \mathrm{L}$ of assay buffer (in which the samples were dissolved later) were pipetted onto 16 spots on a NanoQuantPlate (TecanGroup) as blank. After blanking, $2 \mu \mathrm{L}$ of samples were measured. DNA concentration was then determined by multiplication of the measured absorption coefficient with 50 as a dsDNA specific factor. The same method as for DNA content analysis was employed for RNA content analysis. Here, purification was done with the NucleoSpin RNAII kit (Macherey-Nagel) according to the procedure "total RNA purification from cultured cells and tissue". RNA concentration was determined from absorption measurements at $260 \mathrm{~nm}$, but by multiplication with a factor of 40. Measurement procedure was analogous to the DNA analysis.

Amino acid contents were determined as follows: about $1 \times 10^{8}$ cells were washed with $0.9 \% \mathrm{NaCl}$ solution and re-suspended in $2 \mathrm{M} \mathrm{HCl}$. Cells were incubated in acid at $100^{\circ} \mathrm{C}$ for $24 \mathrm{~h}$. After this hydrolyzation, the solution was neutralized by adding $2 \mathrm{M} \mathrm{NaOH}$ and subsequently analysed by HPLC. Aspartate and glutamate percentages were corrected for a hydrolysis rate of $47.5 \%$ as described in literature [7].

A HPLC method was used to measure the amino acid composition of cell protein [53]. Due to harsh hydrolytic conditions, some amino acid concentrations could not be measured, but were estimated from literature values (see Additional file 1: Table S1).

\section{Cell and metabolite concentration measurements}

Samples were taken once or twice a day. Cell concentration, viability and average cell diameter were determined using the Vi-CELL ${ }^{\mathrm{mm}}$ XR device (Beckman Coulter). Samples for measuring extracellular metabolite concentrations were centrifuged after sampling and the supernatant was stored at $-80^{\circ} \mathrm{C}$ until analysis. Measurement of glucose, lactate and ammonia concentrations was done with a Bioprofile 100 Plus (Nova Biomedical). A HPLC method was used to measure the concentration of pyruvate. Extracellular amino acid concentrations for metabolic flux analysis were determined using a derivatization method and subsequent measurement in a HPLC system [54]. Uric acid concentration was measured with an enzymatic reaction assay kit (Uric Acid Assay Kit, BioVision) including standard curves and controls as described in the manual. Uric acid was only measured at culture start and end. Standard deviations for all concentration measurements (determined by method validations) can be found in Additional file 1: Table S3.

\section{In vitro determination of maximum enzyme activities}

Maximum activities of pyruvate carboxylase (PC), pyruvate dehydrogenase (PDH), glutamine synthetase (GS) and glutaminase (GLNase) in exponentially growing cells were measured. Therefore, cells were harvested from shaker flasks $72 \mathrm{~h}$ after inoculation. After a washing step in $0.9 \% \mathrm{NaCl}$, dry cell pellets were frozen at $-80^{\circ} \mathrm{C}$ and stored until analysis. Enzyme extraction and assays were performed as described for MDCK cells [46]. Three assay parameters had to be optimized before measuring 
CR.pIX cell extracts: pH, amount of cells that are used and - for GLNase and GS activity assay - incubation time. After these pre-tests, CR.pIX cell extracts were measured with the following modifications: a two-fold higher cell concentration as for MDCK cells was necessary for the GLNase and GS assay and the incubation time of the GLNase assay was set to $30 \mathrm{~min}$ instead of $60 \mathrm{~min}$. The assay plates were analyzed in a 96 well plate reader (Tecan) and enzyme activities were calculated from absorption values.

\section{Metabolic network}

A stoichiometric network model of the central metabolism of avian cells (Figure 1, Table 2) was constructed based on KEGG database entries from Gallus gallus (chicken), Meleagris gallopavo (turkey) and Taeniopygia guttata (zebra finch) as well as on information available from previously published networks and from studies on avian metabolism [40]. Overall, the network consists of 97 reactions and 72 metabolites, resulting in a stoichiometric matrix with dimensions $72 \times 97$ and 28 degrees of freedom. All implemented reactions are listed in the Table 2.

Generally, the network includes

- Two compartments: cytosol and mitochondria

- Main pathways of energy metabolism: glycolysis, TCA cycle and oxidative phosphorylation

- Catabolism of amino acids

- Transport of metabolites and corresponding energy demands (as described before [14])

- Synthesis of macromolecules (biomass)

- Synthesis of urea and uric acid

- A simplified/lumped pentose-phosphate pathway (as in [9])

\section{Calculation of extracellular rates}

During the exponential growth phase, metabolism is considered to be in a pseudo steady-state with constant reaction rates [55]. The growth rate $\mu$ was calculated via curve fitting of the viable cell concentration measurements $(\mathrm{X}(\mathrm{t}))$ to:

$$
X(t)=X\left(t_{0}\right) \cdot e^{\mu \cdot\left(t-t_{0}\right)}
$$

Uptake or release rates $v_{i}$ (in unit $[\mu \mathrm{mol} / \mathrm{gDW} / \mathrm{h}]$ of external metabolites $c_{i}$ were computed via curve fitting of the concentration data to:

$$
c_{i}(t)=c_{i}\left(t_{o}\right)+v_{i} \cdot \frac{D W\left(t_{0}\right)}{\mu} \cdot\left(e^{\mu \cdot\left(t-t_{0}\right)}-1\right),
$$

where we applied the experimentally determined cell dry weight and the calculated $\mu$ from Equation (1).
For glutamine, a first order degradation process to ammonia and 5-oxopyrrolidine-2-carboxylic acid was assumed. The rate constant $k_{G l n}=0.0032 \mathrm{~h}^{-1}$ of this process was determined experimentally $(n=3)$ using medium without cells under standard cultivation conditions in a bioreactor. Based on this degradation rate, glutamine and ammonia rates (Equation (2)) were corrected as described elsewhere [56]. To compute standard deviations of the fluxes, we performed a Monte-Carlo simulation and added a normally distributed error with mean zero and corresponding standard deviation (derived from assay validations) at each time point and for each measurement (metabolites and cell concentration). With this, we generated 100,000 random sample data sets and recalculated for each data set the rates of uptake, release and growth. From these simulated data sets, the empirical variances and standard deviations $\sigma_{r_{i}}$ for each of these rates were computed.

\section{Flux variability and metabolic flux analysis}

We restrict our analysis to the time span of exponential growth from $24 \mathrm{~h}$ to $97 \mathrm{~h}$. Within this time interval the quasi steady state assumption holds and, together with the stoichiometric matrix $\mathbf{N}$ and the vector $\mathbf{r}$ of reaction rates (fluxes), the reaction rates can be determined by solving a system of linear equations. Given the measured and known rates, $\mathbf{r}$ and $\mathbf{N}$ can be partitioned into the known $\left(\mathbf{r}_{\mathbf{k}}, \mathbf{N}_{\mathbf{k}}\right)$ and unknown part $\left(\mathbf{r}_{\mathbf{u}}, \mathbf{N}_{\mathbf{u}}\right)$ we can write the steady state equation as

$$
\frac{d c}{d t}=\mathbf{0}=\mathbf{N} \cdot \mathbf{r}=\mathbf{N}_{\mathbf{u}} \mathbf{r}_{\mathbf{u}}+\mathbf{N}_{\mathbf{k}} \mathbf{r}_{\mathbf{k}}
$$

yielding after reformulation the central equation for metabolic flux analysis

$$
\mathbf{N}_{\mathbf{u}} \mathbf{r}_{\mathbf{u}}=-\mathbf{N}_{\mathbf{k}} \mathbf{r}_{\mathbf{k}}
$$

A detailed description of how to further proceed with Equation (3) is given elsewhere [57-59]. If the linear equation system is over-determined, a variance-weighted least squares estimation can be applied to calculate uniquely determined reaction rates. However, Equation (3) usually defines an underdetermined system and, hence, the flux distribution cannot be calculated uniquely. For identifying at least feasible ranges of the fluxes we use flux variability analysis (FVA), an approach that is based on linear programming [27]. Here, the minimal and maximal possible flux that a reaction can have in any flux distribution that is consistent with Equation (3) is calculated separately for each unknown reaction $r_{u, i}$. Further constraints arise by the irreversibility of some reactions (constrained to nonnegative values) or because some reaction rates are fixed to specific (measured or known) values reflecting the given environmental conditions. To avoid unbounded fluxes and 
Table 2 Reactions included in the metabolic network model of CR.pIX cells

\begin{tabular}{|c|c|}
\hline \multicolumn{2}{|r|}{ Uptake rates } \\
\hline r1, Glc & $\mathrm{Glc} \rightarrow \mathrm{Glc}_{\mathrm{cyt}}$ \\
\hline r2, Pyr & $\mathrm{Pyr}+0.33 \mathrm{ATP}_{\mathrm{cyt}} \rightarrow \mathrm{Pyr}_{\mathrm{cyt}}$ \\
\hline $\mathrm{r} 3, \mathrm{O} 2$ & $\mathrm{O}_{2} \rightarrow \mathrm{O}_{2, \mathrm{cyt}}$ \\
\hline r4, Gln & $\mathrm{Gln}+0.33 \mathrm{ATP}_{\text {cyt }} \rightarrow \mathrm{Gln}_{\mathrm{cyt}}$ \\
\hline r5, Glu & $\mathrm{Glu} \mathrm{ATP}_{\mathrm{cyt}} \rightarrow \mathrm{Glu}_{\mathrm{cyt}}$ \\
\hline r6, Ala & Ala $+0.33 \mathrm{ATP}_{\text {cyt }} \rightarrow \mathrm{Ala}_{\text {cyt }}$ \\
\hline r7, Asp & $\mathrm{Asp}+\mathrm{ATP}_{\text {cyt }} \rightarrow \mathrm{Asp}_{\text {cyt }}$ \\
\hline r8, Arg & $\operatorname{Arg}+0.33 \operatorname{ATP}_{\text {cyt }} \rightarrow \operatorname{Arg}_{\text {cyt }}$ \\
\hline r9, Asn & Asn +0.33 ATP $_{\text {cyt }} \rightarrow$ Asn $_{\text {cyt }}$ \\
\hline r10, Cys & Cys $+0.33 \mathrm{ATP}_{\text {cyt }} \rightarrow$ Cys cyt $_{\text {cyt }}$ \\
\hline r11, Gly & Gly $+0.33 \mathrm{ATP}_{\text {cyt }} \rightarrow$ Gly $_{\text {cyt }}$ \\
\hline r12, His & $\mathrm{His}+0.33 \mathrm{ATP}_{\mathrm{cyt}} \rightarrow \mathrm{His}_{\mathrm{cyt}}$ \\
\hline r13, lle & $\left\|\mathrm{e}+0.33 \mathrm{ATP}_{\mathrm{cyt}} \rightarrow\right\| \mathrm{e}_{\mathrm{cyt}}$ \\
\hline r14, Leu & Leu $+0.33 \mathrm{ATP}_{\text {cyt }} \rightarrow$ Leu $_{\text {cyt }}$ \\
\hline r15, Lys & Lys +0.33 ATP $_{\text {cyt }} \rightarrow$ Lys $_{\text {cyt }}$ \\
\hline r16, Val & $\mathrm{Val}+0.33 \mathrm{ATP}_{\text {cyt }} \rightarrow \mathrm{Val}_{\text {cyt }}$ \\
\hline r17, Met & Met $+0.33 \mathrm{ATP}_{\mathrm{cyt}} \rightarrow \mathrm{Met}_{\mathrm{cyt}}$ \\
\hline r18, Phe & Phe +0.33 ATP $_{\text {cyt }} \rightarrow$ Phe $_{\text {cyt }}$ \\
\hline r19, Pro & Pro $+0.33 \mathrm{ATP}_{\text {cyt }} \rightarrow$ Pro $_{\text {cyt }}$ \\
\hline r20, Ser & Ser $+0.33 \mathrm{ATP}_{\text {cyt }} \rightarrow \mathrm{Ser}_{\text {cyt }}$ \\
\hline r21, Thr & $\mathrm{Thr}+0.33 \mathrm{ATP}_{\text {cyt }} \rightarrow \mathrm{Thr}_{\text {cyt }}$ \\
\hline r22, Trp & $\operatorname{Trp}+0.33 \mathrm{ATP}_{\text {cyt }} \rightarrow \operatorname{Trp}_{\text {cyt }}$ \\
\hline r23, Tyr & $\mathrm{Tyr}+0.33 \mathrm{ATP}_{\text {cyt }} \rightarrow \mathrm{Tyr}_{\mathrm{cyt}}$ \\
\hline & Glycolysis \\
\hline
\end{tabular}

r25, F6P

r26, FBP

127, DHAP

r28, GAP

r29, PG

r30, PEP

r31, PEP_Pyr

r32, Pyr_Lac

r33, PDH

r34, R5P

$$
\mathrm{Glc}_{\text {cyt }}+\mathrm{ATP}_{\text {cyt }} \rightarrow{\mathrm{G} 6 \mathrm{P}_{\text {cyt }}}
$$

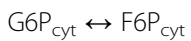

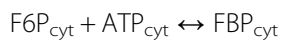$$
\mathrm{FBP}_{\text {cyt }} \leftrightarrow \mathrm{GAP}_{\text {cyt }}+\mathrm{DHAP}_{\text {cyt }}
$$

$\mathrm{DHAP}_{\text {cyt }} \leftrightarrow \mathrm{GAP}_{\text {cyt }}$

$\mathrm{GAP}_{\text {cyt }} \leftrightarrow \mathrm{NADH}_{\text {cyt }}+\mathrm{ATP}_{\text {cyt }}+\mathrm{PG}_{\text {cyt }}$

$P G_{\text {cyt }} \leftrightarrow P P_{\text {cyt }}$

$\mathrm{PEP}_{\text {cyt }} \rightarrow \mathrm{Pyr}_{\mathrm{cyt}}+\mathrm{ATP}_{\text {cyt }}$

$\mathrm{Pyr}_{\mathrm{cyt}}+\mathrm{NADH}_{\mathrm{cyt}} \leftrightarrow \operatorname{Lac}_{\mathrm{cyt}}$

$\mathrm{Pyr}_{\text {mit }}+\mathrm{CoA}_{\text {mit }} \rightarrow \mathrm{AcCoA}_{\text {mit }}+\mathrm{CO}_{2, \text { mit }}+\mathrm{NADH}_{\text {mit }}$

\section{Pentose phosphate pathway}

$\mathrm{G} \mathrm{P}_{\mathrm{cyt}} \rightarrow \mathrm{R} 5 \mathrm{P}_{\mathrm{cyt}}+\mathrm{CO}_{2, \mathrm{cyt}}+2 \mathrm{NADPH}_{\mathrm{cyt}}$

\section{TCA cycle}

r35, OAA $\quad \mathrm{Mal}_{\text {cyt }} \leftrightarrow \mathrm{OAA}_{\text {cyt }}+\mathrm{NADH}_{\text {cyt }}$

r36, Cit

r37, Fum_Mal

$\mathrm{AcCOA}_{\text {cyt }}+\mathrm{OAA}_{\text {cyt }} \rightarrow \mathrm{Cit}_{\text {cyt }}+\mathrm{CoA}_{\text {cyt }}$

r38, Cit mito $_{\text {o }}$

Fum $_{\text {cyt }} \leftrightarrow \mathrm{Mal}_{\mathrm{cyt}}$

r39, OAA mito $_{\text {m }}$

$\mathrm{AcCOA}_{\text {mit }}+\mathrm{OAA}_{\text {mit }} \rightarrow \mathrm{Cit}_{\text {mit }}+\mathrm{CoA}_{\text {mit }}$

r40, Fum_Mal $\left.\right|_{\text {mito }} \quad$ Fum mit $\leftrightarrow \mathrm{Mal}_{\text {mit }}$
Table 2 Reactions included in the metabolic network model of CR.pIX cells (Continued)

\begin{tabular}{ll}
\hline r41, SCoA mito & $\mathrm{aKG}_{\text {mit }}+\mathrm{CoA}_{\text {mit }} \rightarrow$ SuccCoA $_{\text {mit }}+\mathrm{CO}_{2, \text { mit }}+N A D H_{\text {mit }}$ \\
r42, Fum mito & SuccCoA $_{\text {mit }} \leftrightarrow$ Fum mit $_{\text {mit }}+\mathrm{CoA}_{\text {mit }}+A T P_{\text {mit }}+F A D H_{2, \text { mit }}$ \\
r43, aKG mito & Cit $_{\text {mit }} \leftrightarrow \mathrm{aKG} G_{\text {mit }}+\mathrm{CO}_{2 \text {,mit }}+\mathrm{NADH}_{\text {mit }}$
\end{tabular}

\section{Anaplerosis}

r44, Ana_Pyrl $\quad \mathrm{Mal}_{\mathrm{cyt}} \rightarrow \mathrm{Pyr}_{\mathrm{cyt}}+\mathrm{CO}_{2, \mathrm{cyt}}+\mathrm{NADPH}_{\mathrm{cyt}}$

r45, Ana_Pyrll $\quad \mathrm{Mal}_{\text {mit }} \leftrightarrow \mathrm{Pyr}_{\text {mit }}+\mathrm{CO}_{2 \text {,mit }}+\mathrm{NADPH}_{\text {mit }}$

r46, PC

$\mathrm{Pyr}_{\text {mit }}+\mathrm{CO}_{2, \text { mit }}+\mathrm{ATP}_{\text {mit }} \rightarrow \mathrm{OAA}_{\text {mit }}$

\section{Amino acid catabolism}

r47, GDH

$r 48, \mathrm{GS}$

$\mathrm{Glu}_{\text {mit }} \leftrightarrow \mathrm{aKG}_{\text {mit }}+\mathrm{Amm}_{\text {mit }}+\mathrm{NADPH}_{\text {mit }}$

r49, Ala $_{\text {cat }}$

$\mathrm{Gln}_{\text {cyt }} \leftrightarrow \mathrm{Glu}_{\text {cyt }}+\mathrm{Amm}_{\text {cyt }}+\mathrm{ATP}_{\text {cyt }}$

r50, Asn_Asp

$\mathrm{Ala}_{\mathrm{cyt}}+\mathrm{aKG}_{\mathrm{cyt}} \leftrightarrow \mathrm{Pyr}_{\mathrm{cyt}}+\mathrm{Glu}_{\mathrm{cyt}}$

r51, His cat

$\mathrm{Asn}_{\mathrm{cyt}} \leftrightarrow \mathrm{Asp}_{\mathrm{cyt}}+\mathrm{Amm}_{\mathrm{cyt}}$

r52, $\|_{\text {cat }}$

$\mathrm{His}_{\mathrm{cyt}} \rightarrow \mathrm{Glu}_{\mathrm{cyt}}+2 \mathrm{Amm}_{\mathrm{cyt}}+\mathrm{CO}_{2, \mathrm{cyt}}$

$\| \mathrm{e}_{\mathrm{cyt}}+\mathrm{aKG}_{\mathrm{cyt}}+2 \mathrm{CoA}_{\mathrm{mit}}+\mathrm{ATP}_{\mathrm{mit}} \rightarrow \mathrm{SuccCoA}_{\text {mit }}+$ $\mathrm{AcCOA}_{\text {mit }}+\mathrm{Glu}_{\mathrm{cyt}}+\mathrm{NADH}_{\mathrm{mit}}+\mathrm{FADH}$, mit

r53, Leucat

r54, Lys cat

$\mathrm{Leu}_{\mathrm{cyt}}+\mathrm{aKG}_{\mathrm{cyt}}+3 \mathrm{CoA}_{\mathrm{mit}}+2 \mathrm{ATP}_{\mathrm{mit}} \rightarrow 3 \mathrm{AcCOA}_{\mathrm{mit}}+$ $\mathrm{Glu}_{\mathrm{cyt}}+\mathrm{NADH}_{\text {mit }}+\mathrm{FADH} \mathrm{H}_{2 \text { mit }}$

r55, Met $_{\text {cat }}$

$\mathrm{Lys}_{\mathrm{gtt}}+2 \mathrm{aKG}_{\mathrm{cyt}}+2 \mathrm{CoA}_{\mathrm{mit}}+\mathrm{NADPH}_{\mathrm{cyt}} \rightarrow 2 \mathrm{AcCoA}_{\mathrm{mit}}+$ $2 \mathrm{Glu}_{\mathrm{cyt}}+2 \mathrm{CO}_{2, \text { mit }}+2 \mathrm{NADH}_{\mathrm{cyt}}+2 \mathrm{NADH}_{\text {mit }}+\mathrm{FADH}_{2 \text {,mit }}$

r56, Phe $_{\text {cat }}$

$\mathrm{Met}_{\text {cyt }}+\mathrm{Ser}_{\text {cyt }}+\mathrm{CoA}_{\text {mit }}+3 \mathrm{ATP}_{\text {cyt }}+\mathrm{ATP}_{\text {mit }} \rightarrow \mathrm{Cys}_{\mathrm{cyt}}+$ SuccCoA $A_{\text {mit }}+\mathrm{Amm}_{\mathrm{cyt}}+\mathrm{NADH}_{\text {mit }}+\mathrm{CO}_{2, \mathrm{cyt}}$

157, Pro cat

$\mathrm{Phe}_{\mathrm{cyt}}+\mathrm{O}_{2, \mathrm{cyt}}+\mathrm{NADPH}_{\mathrm{cyt}} \rightarrow \mathrm{Tyr}_{\mathrm{cyt}}$

r58, $\operatorname{Thr}_{\text {cat }}$

r59, $\operatorname{Trp}_{\mathrm{cat}}$

$\mathrm{PrO}_{\text {cyt }} \leftrightarrow \mathrm{Glu}_{\mathrm{cyt}}+2 \mathrm{NADH}_{\mathrm{cyt}}$

$\mathrm{Thr}_{\text {cyt }} \rightarrow \mathrm{Pyr}_{\text {mit }}+\mathrm{Amm}_{\text {mit }}+\mathrm{CO}_{2, \mathrm{mit}}+\mathrm{NADH}_{\mathrm{cyt}}+$

$\mathrm{NADH}_{\text {mit }}+\mathrm{FADH}_{2, \text { mit }}$

$\mathrm{Trp}_{\mathrm{cyt}}+2 \mathrm{CoA}_{\mathrm{mit}}+3 \mathrm{O}_{2, \mathrm{cyt}}+\mathrm{NADPH}_{\mathrm{cyt}} \rightarrow \mathrm{Ala}_{\mathrm{cyt}}+2$ $\mathrm{AcCOA}$ mit $+\mathrm{Amm}_{\mathrm{cyt}}+2 \mathrm{CO}_{2, \mathrm{mit}}+2 \mathrm{CO}_{2, \mathrm{cyt}}+\mathrm{NADH}_{\mathrm{cyt}}+$ $2 \mathrm{NADH}_{\text {mit }}+\mathrm{FADH}_{2, \text { mit }}$

$r 60, V_{\text {cat }}$

$\mathrm{Val}_{\mathrm{cyt}}+\mathrm{aKG}_{\mathrm{cyt}}+\mathrm{CoA}_{\text {mit }}+\mathrm{ATP}_{\mathrm{mit}} \rightarrow \mathrm{SucCCOA}_{\text {mit }}+\mathrm{Glu}_{\mathrm{cyt}}+$ $\mathrm{CO}_{2, \mathrm{cyt}}+3 \mathrm{NADH}_{\text {mit }}+\mathrm{FADH}_{2, \text { mit }}$

r61, Tyr cat

$\mathrm{Tyr}_{\mathrm{cyt}}+\mathrm{aKG}_{\mathrm{cyt}}+2 \mathrm{CoA}_{\mathrm{cyt}}+2 \mathrm{O}_{2, \mathrm{cyt}} \rightarrow \mathrm{Fum}_{\mathrm{cyt}}+2$

$\mathrm{AcCoA}_{\mathrm{cyt}}+\mathrm{Glu}_{\mathrm{cyt}}+\mathrm{CO}_{2, \mathrm{cyt}}$

r62, Ser cat

$\mathrm{Ser}_{\text {cyt }} \leftrightarrow \mathrm{Pyr}_{\text {cyt }}+\mathrm{Amm}_{\text {cyt }}$

r63, Cys cat

$\mathrm{Cys}_{\mathrm{cyt}}+\mathrm{aKG}_{\mathrm{cyt}}+\mathrm{O}_{2, \mathrm{cyt}} \rightarrow \mathrm{Pyr}_{\mathrm{cyt}}+\mathrm{Glu}_{\mathrm{cyt}}$

r64, Asp cat

$\mathrm{Asp}_{\text {cyt }}+\mathrm{aKG}_{\text {mit }} \leftrightarrow \mathrm{Glu}_{\mathrm{cyt}}+\mathrm{OAA}_{\mathrm{mit}}$

r65, $\operatorname{Arg}_{\text {cat }}$

$\operatorname{Arg}_{\text {cyt }}+\mathrm{aKG}_{\mathrm{cyt}} \rightarrow 2 \mathrm{Glu}_{\mathrm{cyt}}+U_{\text {rea }} \mathrm{cyt}+\mathrm{NADH}_{\mathrm{cyt}}$

\section{MTHF \& uric acid synthesis}

r66, MTHF_I

$\mathrm{Ser}_{\text {cyt }}+\mathrm{THF}_{\text {cyt }} \rightarrow \mathrm{Gly}_{\text {cyt }}+\mathrm{MTHF}_{\text {cyt }}$

r67, MTHF_II

$\mathrm{Gly}_{\mathrm{cyt}}+\mathrm{THF}_{\mathrm{cyt}} \rightarrow \mathrm{NADH}_{\mathrm{cyt}}+\mathrm{CO}_{2, \mathrm{cyt}}+\mathrm{Amm}_{\mathrm{cyt}}+\mathrm{MTHF}_{\mathrm{cyt}}$

r68, UricAcid $\quad \mathrm{Asp}_{\text {cyt }}+2 \mathrm{Gln}_{\text {cyt }}+\mathrm{Gly}_{\mathrm{cyt}}+2 \mathrm{MTHF}_{\mathrm{cyt}}+7 \mathrm{ATP}_{\text {cyt }}+$

$\mathrm{CO}_{2, \mathrm{cyt}} \rightarrow$ UricAcid $_{\mathrm{cyt}}+$ Fum $_{\mathrm{cyt}}+2 \mathrm{Glu}_{\mathrm{cyt}}+2 \mathrm{THF}_{\mathrm{cyt}}$

\section{Lipid synthesis}

r69, $\mathrm{CH}_{\text {Lip }} \quad 18 \mathrm{AcCoA}_{\text {cyt }}+18 \mathrm{ATP}_{\text {cyt }}+11 \mathrm{O}_{2, \mathrm{cyt}}+27 \mathrm{NADPH}_{\text {cyt }} \rightarrow$ $\mathrm{CH}+18 \mathrm{CoA}_{\mathrm{cyt}}+9 \mathrm{CO}_{2, \mathrm{cyt}}$

$r 70, P C_{\text {Lip }}$

$\mathrm{GAP}_{\text {cyt }}+\mathrm{Ser}_{\mathrm{cyt}}+27.6 \mathrm{ATP}_{\mathrm{cyt}}+17.6 \mathrm{AcCoA}_{\mathrm{cyt}}+4$ $\mathrm{MTHF}_{\mathrm{cyt}}+2 \mathrm{NADH}_{\mathrm{cyt}}+31.2 \mathrm{NADPH}_{\mathrm{cyt}} \rightarrow \mathrm{PC}+17.6$

$\mathrm{CoA}_{\text {cyt }}+4 \mathrm{THF}_{\text {cyt }}$

$r 71, P E_{\text {Lip }}$ 
Table 2 Reactions included in the metabolic network model of CR.pIX cells (Continued)

\begin{tabular}{|c|c|}
\hline r72, $\mathrm{PS}_{\text {Lip }}$ & $\begin{array}{l}\mathrm{GAP}_{\mathrm{cyt}}+\mathrm{Ser}_{\mathrm{cyt}}+18.6 \mathrm{ATP}_{\mathrm{cyt}}+17.6 \mathrm{AcCoA}_{\mathrm{cyt}}+2 \mathrm{MTHF}_{\mathrm{cyt}}+ \\
2 \mathrm{NADH}_{\mathrm{cyt}}+31.2 \mathrm{NADPH}_{\mathrm{cyt}} \rightarrow \mathrm{PS}+17.6 \mathrm{CoA}_{\mathrm{cyt}}+2 \mathrm{THF}_{\mathrm{cyt}}\end{array}$ \\
\hline r73, $P G_{L i p}$ & $\begin{array}{l}2 \mathrm{GAP}_{\text {cyt }}+17.6 \mathrm{ATP}_{\text {cyt }}+17.6 \mathrm{AcCoA}_{\text {cyt }}+4 \mathrm{NADH}_{\text {cyt }}+ \\
\text { 31.2 } \mathrm{NADPH}_{\text {cyt }} \rightarrow \mathrm{PGL}+17.6 \mathrm{CoA}_{\text {cyt }}\end{array}$ \\
\hline r74, Pl Lip & $\begin{array}{l}\mathrm{GAP}_{\text {cyt }}+\mathrm{G}_{\mathrm{CP}} \text { cyt }+17.6 \mathrm{ATP}_{\text {cyt }}+17.6 \mathrm{AcCoA}_{\mathrm{cyt}}+ \\
2 \mathrm{NADH}_{\mathrm{cyt}}+31.2 \mathrm{NADPH}_{\mathrm{cyt}} \rightarrow \mathrm{PI}+17.6 \mathrm{CoA}_{\mathrm{cyt}}\end{array}$ \\
\hline r75, SMLip & $\begin{array}{l}2 \mathrm{Ser}_{\mathrm{cyt}}+27.8 \mathrm{ATP}_{\mathrm{cyt}}+16.8 \mathrm{AcCOA}_{\mathrm{cyt}}+3 \mathrm{MTHF}_{\mathrm{cyt}}+2 \\
\mathrm{NADH}_{\mathrm{cyt}}+29.6 \mathrm{NADPH}_{\mathrm{cyt}} \rightarrow \mathrm{SM}+16.8 \mathrm{CoA}_{\mathrm{cyt}}+3 \mathrm{THF}_{\mathrm{cyt}}\end{array}$ \\
\hline r76, DPG Lip & $\begin{array}{l}3 \mathrm{GAP}_{\text {cyt }}+35.2 \mathrm{ATP}_{\mathrm{cyt}}+35.2 \mathrm{AcCoA}_{\text {cyt }}+6 \mathrm{NADH}_{\text {cyt }}+ \\
\text { 62.4 NADPH }\end{array}$ \\
\hline
\end{tabular}

\section{Release rates}

\begin{tabular}{|c|c|}
\hline r77, ATP ${ }_{\text {main }}$ & ATP $_{\text {cyt }} \rightarrow$ maintenance \\
\hline r78, Lac out & $\operatorname{Lac}_{\mathrm{cyt}} \rightarrow \mathrm{Lac}$ \\
\hline r79, Ala out $_{\text {out }}$ & $\mathrm{Ala}_{\mathrm{cyt}} \rightarrow \mathrm{Ala}$ \\
\hline r80, UricAcid ${ }_{\text {out }}$ & Uric acid $_{\text {cyt }} \rightarrow$ Uric acid \\
\hline r81, Urea out & Urea $_{\text {cyt }} \rightarrow$ Urea \\
\hline r82, Amm out & $\mathrm{Amm}_{\mathrm{cyt}} \rightarrow \mathrm{Amm}$ \\
\hline $3, \mathrm{CO}_{2}$ out & $\mathrm{CO}_{2, \mathrm{cyt}} \rightarrow \mathrm{CO}_{2}$ \\
\hline , Pyr out & $\mathrm{Pyr}_{\mathrm{cyt}} \rightarrow \mathrm{Pyr}$ \\
\hline
\end{tabular}

Transport reactions, oxidative phosphorylation

\begin{tabular}{|c|c|}
\hline r85, $\mathrm{NADH}_{\text {cyt,trans }}$ & $\mathrm{NADH}_{\text {cyt }} \leftrightarrow \mathrm{NADH}_{\text {mit }}$ \\
\hline r86, ATP trans & $\mathrm{ATP}_{\text {cyt }} \leftrightarrow \mathrm{ATP}_{\text {mitt }}$ \\
\hline r87, $\mathrm{CO}_{2}$ trans & $\mathrm{CO}_{2, \mathrm{cyt}} \leftrightarrow \mathrm{CO}_{2, \mathrm{mit}}$ \\
\hline r88, MAL trans & $\mathrm{Mal}_{\mathrm{cyt}}+\mathrm{Cit}_{\text {mit }} \leftrightarrow \mathrm{Mal}_{\mathrm{mit}}+\mathrm{Cit}_{\mathrm{cyt}}$ \\
\hline r89, Glutrans & $\mathrm{Glu}_{\mathrm{cyt}} \leftrightarrow \mathrm{Glu}_{\mathrm{mit}}$ \\
\hline r90, Pyr $r_{\text {trans }}$ & $\mathrm{Pyr}_{\text {cyt }} \leftrightarrow$ Pyr $r_{\text {mit }}$ \\
\hline r91, aKG trans & $\mathrm{aKG}_{\mathrm{cyt}} \leftrightarrow \mathrm{aKG}$ mit \\
\hline 2, Amm trans & $A m m_{c y t} \leftrightarrow A_{m m}$ mit \\
\hline 3, $\mathrm{FADH}_{\mathrm{ox}}$ & $\mathrm{O}_{2, \mathrm{cyt}}+2 \mathrm{FADH}_{2, \mathrm{mit}} \rightarrow 3 \mathrm{ATP}_{\text {mit }}$ \\
\hline r94, $\mathrm{NADH}_{\text {mit,trans }}$ & $\mathrm{NADH}_{\text {mit }} \leftrightarrow \mathrm{NADPH}_{\text {mit }}$ \\
\hline 5, $\mathrm{NADH}_{\mathrm{ox}}$ & $\mathrm{O}_{2, \mathrm{cyt}}+2 \mathrm{NADH}_{\text {mit }} \rightarrow 5 \mathrm{ATP}_{\text {mit }}$ \\
\hline NADH $\mathrm{Nyt}_{\text {cytrans }}$ & $\mathrm{NADH}_{\mathrm{cyt}} \leftrightarrow \mathrm{NADPH}_{\mathrm{cyt}}$ \\
\hline
\end{tabular}

\section{Synthesis of macromolecules and biomass}

r97, $\mu \quad 0.552$ proteins +0.263 carbohydrates +0.131 lipids + $0.023 \mathrm{DNA}+0.031 \mathrm{RNA} \rightarrow$ biomass

Proteins [1 g] = 955.79 Asp cyt $+1344.29 \mathrm{Ala}_{\mathrm{cyt}}+543.16 \mathrm{Gln}_{\mathrm{cyt}}++817.99$ $\mathrm{Glu}_{\text {cyt }}+1024.72 \mathrm{Arg}_{\mathrm{cyt}}+362.10 \mathrm{Asn}_{\mathrm{cyt}}+19.61 \mathrm{Cys}_{\mathrm{cyt}}+913.16 \mathrm{Gly}_{\mathrm{cyt}}+271.58$ $\mathrm{His}_{\mathrm{cyt}}+240.54 \mathrm{lle}_{\mathrm{cyt}}+588.41 \mathrm{Leu}_{\mathrm{cyt}}+724.21 \mathrm{Lys}_{\mathrm{cyt}}+191.97 \mathrm{Val}_{\mathrm{cyt}}+114.57$ $\mathrm{Met}_{\mathrm{cyt}}+201.91 \mathrm{Phe}_{\mathrm{cyt}}+205.97 \mathrm{PrO}_{\mathrm{cyt}}+247.44 \mathrm{Ser}_{\mathrm{cyt}}+202.07 \mathrm{Thr}_{\mathrm{cyt}}+21.17$ $\operatorname{Trp}_{\text {cyt }}+61.87 \mathrm{Tyr}_{\mathrm{cyt}}+24046.3 \mathrm{ATP}_{\mathrm{cyt}}$

Lipids $[1 \mathrm{~g}]=181 \mathrm{CH}+661.4 \mathrm{PC}+250.3 \mathrm{PE}+90.9 \mathrm{PI}+24.9 \mathrm{PS}+12.6 \mathrm{PGL}+$ 81.4 SM + 26.8 DPG

DNA $[1 \mathrm{~g}]=3009 \mathrm{R}_{\mathrm{cyt}}+3912 \mathrm{Asp}_{\mathrm{cyt}}+5717 \mathrm{Gln}_{\mathrm{cyt}}+-2106 \mathrm{NADH}_{\mathrm{cyt}}+1505$ $\mathrm{Gly}_{\mathrm{cyt}}+22569 \mathrm{ATP}_{\mathrm{cyt}}+903 \mathrm{NADH}_{\mathrm{mit}}+-2407 \mathrm{Mal}_{\mathrm{cyt}}+903 \mathrm{NADPH}_{\mathrm{cyt}}+-5717$ $\mathrm{Glu}_{\mathrm{cyt}}+5417 \mathrm{MTHF}_{\mathrm{cyt}}+-5417 \mathrm{THF}_{\mathrm{cyt}}$

RNA [1 g] $=3020 \mathrm{R}^{2} \mathrm{P}_{\text {cyt }}+3606 \mathrm{Asp}_{\text {cyt }}+6316 \mathrm{Gln}_{\text {cyt }}+293 \mathrm{O}_{2, \text { cyt }}+-2435$ $\mathrm{NADH}_{\text {cyt }}+1477 \mathrm{Gly}_{\text {cyt }}+22614 \mathrm{ATP}_{\text {cyt }}+586 \mathrm{NADH}_{\text {mit }}+-2069 \mathrm{Mal}_{\text {cyt }}+-2954$ $\mathrm{NADPH}_{\text {cyt }}+-6316 \mathrm{Glu}_{\mathrm{cyt}}+4431 \mathrm{MTHF}_{\mathrm{cyt}}+-4431 \mathrm{THF}_{\mathrm{cyt}}$

Carbohydrates $[1 \mathrm{~g}]=6172.8 \mathrm{G}_{\mathrm{cyt}}+21605 \mathrm{ATP}_{\text {cyt }}$ to reflect thermodynamic limits under physiological conditions, upper bounds of unknown reaction rates were set to $10000 \mu \mathrm{mol} / \mathrm{gDW} / \mathrm{h}$. The optimization problems studied by FVA then read

$$
\begin{gathered}
r_{u, i}^{\min }=\min _{r} r_{u, i} \quad \text { OR } \quad r_{u, i}^{\max }=\max _{r} r_{u, i} \\
\text { s.t. } \\
\mathbf{N}_{\mathbf{u}} \mathbf{r}_{\mathbf{u}}=-\mathbf{N}_{\mathbf{k}} \mathbf{r}_{\mathbf{k}} \\
0 \leq r_{i} \leq 10000 \quad \forall i \text { reaction } i \text { irreversible } \\
-10000 \leq r_{i} \leq 10000 \quad \forall i \text { reaction } i \text { reversible }
\end{gathered}
$$

As a result from the $2 * u$ optimizations $(u=$ number of unknown fluxes), we obtained the physiologically feasible flux range for the unknown reactions. Moreover, if the computed minimal and maximal rate of a reaction coincide $\left(r_{u, i}^{\min }=r_{u, i}^{\max }\right)$, the reaction rate follows to be uniquely determined. Note that FVA as described above does not make any assumption about biological objectives in contrast to flux balance analysis [59]. The objective function in equation (4) only serves as a tool to identify the feasible flux ranges. This approach has also been used to estimate flux distributions in $\mathrm{CHO}$ cells and was introduced under the term flux-spectrum [60].

We define two scenarios where we consider different sets of constraints. In scenario 1, we applied the measured rate values plus/minus their corresponding standard deviations as upper/lower boundaries for the corresponding rates. In case that the lower boundary of an uptake rate becomes negative, we set it to zero. Rates that were measured not to be active (e.g. uric acid excretion and alanine uptake) were also fixed to zero. No further constraints were used so that the results obtained with this scenario are robust against measurement errors and assumptions on reaction activities. However, since the system is underdetermined with these constraints, only flux ranges can be calculated via FVA.

In scenario 2, we set the measured uptake/excretion rates as fixed constraints. To resolve the anaplerotic fluxes and since the corresponding flux range contains zero (see Results), we assumed the pyruvate-carboxylase (r46) to be inactive. This assumption is biologically reasonable as it is often described and assumed to be negligible in transformed cell cultures (e.g. in $[25,61])$ and supported by our enzyme measurements. With these constraints the network is over-determined with two degrees of redundancy. By applying MFA with a variance-weighted least squares estimation [57], we can calculate a unique flux distribution. To avoid a significant deviation of the estimated against the measured growth rate, we set the measurement variance of the growth rate to $1 \times 10^{-9}$ in scenario 2 .

All computations presented in this study were performed with our software CellNetAnalyzer, a MATLAB toolbox with graphical user interface facilitating metabolic network 
analysis [28]. It can be downloaded from www.mpimagdeburg.mpg.de/projects/cna/cna.html, and the network project files will be made available on this site within CellNetAnalyzer's model repository.

\section{Additional file}

Additional file 1: Table S1. Amino acid composition of cell protein from CR.pIX cells and other cell lines. Table S2. Calculated rate ranges (scenario 1; by FVA) or rates (scenario 2; by MFA) for CR.plX cells cultured in stirred tank reactors. Table S3. Measured concentrations, standard deviations of validated assays, and measurement devices.

\section{Competing interests}

Patent applications covering avian cell lines (including AGE1.CR.pIX) have been filed by I. Jordan.

\section{Authors' contributions}

$\mathrm{VL}$ and $\mathrm{OH}$ conceived the experiments or calculations, interpreted the data and drafted the manuscript. IJ and YG edited the manuscript and participated in planning the experiments. HB helped in data analyses and manuscript drafting. SK contributed to the conception of the study and edited the manuscript. UR helped in drafting the manuscript and generally supervised the project. All authors read and approved the final manuscript.

\section{Acknowledgements}

The authors thank C. Best, N. Wynserski, I. Behrendt and S. König for their excellent technical assistance and A. Lagoda for her advice in RNA, DNA and protein quantification. Also, advice and assistance by Anne-Kareen Blechert in enzyme activity assays was highly appreciated.

\section{Author details}

${ }^{1}$ Max Planck Institute for Dynamics of Complex Technical Systems, Sandtorstr. 1, 39106 Magdeburg, Germany. ${ }^{2}$ Current address: ProBioGen AG, Goethestr. 54, 13086 Berlin, Germany. ${ }^{3}$ Cell Culture Technology, Bielefeld University, Universitätsstr. 25, 33615 Bielefeld, Germany. ${ }^{4}$ Bioprocess Engineering, Otto von Guericke University Magdeburg, Universitätsplatz 2, 39106 Magdeburg, Germany.

Received: 31 October 2013 Accepted: 16 July 2014

Published: 30 July 2014

\section{References}

1. Butler M: Optimisation of the cellular metabolism of glycosylation for recombinant proteins produced by Mammalian cell systems. Cytotechnology 2006, 50(1-3):57-76

2. Lim Y, Wong NS, Lee $Y Y$, Ku SC, Wong DC, Yap MG: Engineering mammalian cells in bioprocessing - current achievements and future perspectives. Biotechnol Appl Biochem 2010, 55(4):175-189.

3. Blanchard TJ, Alcami A, Andrea P, Smith GL: Modified vaccinia virus Ankara undergoes limited replication in human cells and lacks several immunomodulatory proteins: implications for use as a human vaccine. J Gen Virol 1998, 79(Pt 5):1159-1167.

4. Draper SJ, Heeney JL: Viruses as vaccine vectors for infectious diseases and cancer. Nat Rev Microbiol 2010, 8(1):62-73.

5. Jordan I, Vos A, Beilfuss S, Neubert A, Breul S, Sandig V: An avian cell line designed for production of highly attenuated viruses. Vaccine 2009 27(5):748-756.

6. Lohr V, Rath A, Genzel Y, Jordan I, Sandig V, Reichl U: New avian suspension cell lines provide production of influenza virus and MVA in serum-free media: studies on growth, metabolism and virus propagation. Vaccine 2009, 27(36):4975-4982.

7. Nadeau I, Sabatie J, Koehl M, Perrier M, Kamen A: Human 293 cell metabolism in low glutamine-supplied culture: interpretation of metabolic changes through metabolic flux analysis. Metab Eng 2000, 2(4):277-292.
8. Nadeau I, Jacob D, Perrier M, Kamen A: 293 SF metabolic flux analysis during cell growth and infection with an adenoviral vector. Biotechnol Prog 2000, 16(5):872-884.

9. Niklas J, Schrader E, Sandig V, Noll T, Heinzle E: Quantitative characterization of metabolism and metabolic shifts during growth of the new human cell line AGE1.HN using time resolved metabolic flux analysis. Bioprocess Biosyst Eng 2011, 34(5):533-545.

10. Priesnitz C, Niklas J, Rose T, Sandig V, Heinzle E: Metabolic flux rearrangement in the amino acid metabolism reduces ammonia stress in the alpha1-antitrypsin producing human AGE1.HN cell line. Metab Eng 2012, 14(2):128-137.

11. Altamirano C, Illanes A, Casablancas A, Gamez X, Cairo JJ, Godia C: Analysis of $\mathrm{CHO}$ cells metabolic redistribution in a glutamate-based defined medium in continuous culture. Biotechnol Prog 2001, 17(6):1032-1041.

12. Teixeira A, Cunha AE, Clemente JJ, Moreira JL, Cruz HJ, Alves PM, Carrondo MJ, Oliveira R: Modelling and optimization of a recombinant BHK-21 cultivation process using hybrid grey-box systems. J Biotechno/ 2005 118(3):290-303.

13. Sidorenko Y, Wahl A, Dauner M, Genzel Y, Reichl U: Comparison of metabolic flux distributions for MDCK cell growth in glutamine- and pyruvate-containing media. Biotechnol Prog 2008, 24(2):311-320.

14. Wahl A, Sidorenko Y, Dauner M, Genzel Y, Reichl U: Metabolic flux model for an anchorage-dependent MDCK cell line: characteristic growth phases and minimum substrate consumption flux distribution. Biotechnol Bioeng 2008, 101(1):135-152.

15. Bonarius HP, Houtman JH, Schmid G, de Gooijer CD, Tramper J: Metabolicflux analysis of hybridoma cells under oxidative and reductive stress using mass balances. Cytotechnology 2000, 32(2):97-107.

16. Bonarius HP, Hatzimanikatis V, Meesters KP, de Gooijer CD, Schmid G, Tramper J: Metabolic flux analysis of hybridoma cells in different culture media using mass balances. Biotechnol Bioeng 1996, 50(3):299-318.

17. Bernal V, Carinhas N, Yokomizo AY, Carrondo MJ, Alves PM: Cell density effect in the baculovirus-insect cells system: a quantitative analysis of energetic metabolism. Biotechnol Bioeng 2009, 104(1):162-180.

18. Carinhas N, Bernal V, Yokomizo AY, Carrondo MJ, Oliveira R, Alves PM: Baculovirus production for gene therapy: the role of cell density, multiplicity of infection and medium exchange. Appl Microbiol Biotechnol 2009, 81(6):1041-1049.

19. Kovacevic Z, Brkljac O, Bajin K: Control and function of the transamination pathways of glutamine oxidation in tumour cells. Biochem J 1991, 273(Pt 2):271-275.

20. Moreadith RW, Lehninger AL: The pathways of glutamate and glutamine oxidation by tumor cell mitochondria. Role of mitochondrial NAD(P) +-dependent malic enzyme. J Biol Chem 1984, 259(10):6215-6221.

21. Reitzer $L$, Wice BM, Kennell D: Evidence that glutamine, not sugar, is the major energy source for cultured HeLa cells. J Biol Chem 1979, 254(8):2669-2676.

22. Glacken MW, Fleischaker RJ, Sinskey AJ: Reduction of waste product excretion via nutrient control: possible strategies for maximizing product and cell yields on serum in cultures of mammalian cells. Biotechnol Bioeng 1986, 28(9):1376-1389.

23. Miller WM, Blanch HW, Wilke CR: A kinetic analysis of hybridoma growth and metabolism in batch and continuous suspension culture: effect of nutrient concentration, dilution rate, and pH. Biotechnol Bioeng 1988, 32(8):947-965.

24. Boghigian BA, Seth G, Kiss R, Pfeifer BA: Metabolic flux analysis and pharmaceutical production. Metab Eng 2010, 12(2):81-95.

25. Quek LE, Dietmair S, Kromer JO, Nielsen LK: Metabolic flux analysis in mammalian cell culture. Metab Eng 2010, 12(2):161-171.

26. Ahn WS, Antoniewicz MR: Metabolic flux analysis of $\mathrm{CHO}$ cells at growth and non-growth phases using isotopic tracers and mass spectrometry. Metab Eng 2011, 13(5):598-609.

27. Mahadevan $\mathrm{R}$, Schilling $\mathrm{CH}$ : The effects of alternate optimal solutions in constraint-based genome-scale metabolic models. Metab Eng 2003, 5(4):264-276.

28. Klamt S, Saez-Rodriguez J, Gilles ED: Structural and functional analysis of cellular networks with Cell NetAnalyzer. BMC Syst Biol 2007, 1:2.

29. Xie L, Wang DI: Applications of improved stoichiometric model in medium design and fed-batch cultivation of animal cells in bioreactor. Cytotechnology 1994, 15(1-3):17-29.

30. Zupke C, Stephanopoulos G: Intracellular flux analysis in hybridomas using mass balances and in vitro (13) C nmr. Biotechnol Bioeng 1995 45(4):292-303. 
31. Carnicer M, Baumann K, Toplitz I, Sanchez-Ferrando F, Mattanovich D, Ferrer $\mathrm{P}$, Albiol J: Macromolecular and elemental composition analysis and extracellular metabolite balances of Pichia pastoris growing at different oxygen levels. Microb Cell Fact 2009, 8:65.

32. Selvarasu S, Ho YS, Chong WP, Wong NS, Yusufi FN, Lee YY, Yap MG, Lee DY: Combined in silico modeling and metabolomics analysis to characterize fed-batch CHO cell culture. Biotechnol Bioeng 2012, 109(6):1415-1429.

33. Ferrance JP, Goel A, Ataai MM: Utilization of glucose and amino acids in insect cell cultures: quantifying the metabolic flows within the primary pathways and medium development. Biotechnol Bioeng 1993, 42(6):697-707.

34. Xie L, Wang Dl: Fed-batch cultivation of animal cells using different medium design concepts and feeding strategies. Biotechnol Bioeng 1994, 43(11):1175-1189.

35. Lohr V, Genzel Y, Jordan I, Katinger D, Mahr S, Sandig V, Reichl U: Live attenuated influenza viruses produced in a suspension process with avian AGE1.CR.pIX cells. BMC Biotechnol 2012, 12:79.

36. Niklas J, Priesnitz C, Rose T, Sandig V, Heinzle E: Primary metabolism in the new human cell line AGE1.HN at various substrate levels: increased metabolic efficiency and alpha1-antitrypsin production at reduced pyruvate load. App/ Microbiol Biotechnol 2012, 93(4):1637-1650.

37. Schneider M, Marison IW, von Stockar U: The importance of ammonia in mammalian cell culture. J Biotechnol 1996, 46(3):161-185.

38. Yang $M$, Butler $M$ : Effect of ammonia on the glycosylation of human recombinant erythropoietin in culture. Biotechnol Prog 2000 16(5):751-759.

39. Slivac I, Blajic V, Radosevic K, Kniewald Z, Gaurina Srcek V: Influence of different ammonium, lactate and glutamine concentrations on CCO cell growth. Cytotechnology 2010, 62(6):585-594

40. Stevens L: Avian Biochemistry and Molecular Biology. Cambridge: Cambridge University Press; 1996.

41. Fitzpatrick $L$, Jenkins $H A$, Butler M: Glucose and glutamine metabolism of a murine B-lymphocyte hybridoma grown in batch culture. Appl Biochem Biotechnol 1993, 43(2):93-116.

42. Neermann J, Wagner R: Comparative analysis of glucose and glutamine metabolism in transformed mammalian cell lines, insect and primary liver cells. J Cell Physiol 1996, 166(1):152-169.

43. Xie L, Wang DI: Energy metabolism and ATP balance in animal cell cultivation using a stoichiometrically based reaction network. Biotechnol Bioeng 1996, 52(5):591-601.

44. Zamorano F, Wouwer AV, Bastin G: A detailed metabolic flux analysis of an underdetermined network of CHO cells. J Biotechnol 2010, 150(4):497-508.

45. Janke R, Genzel Y, Handel N, Wahl A, Reichl U: Metabolic adaptation of MDCK cells to different growth conditions: effects on catalytic activities of central metabolic enzymes. Biotechnology and bioengineering 2011, 108(11):2691-2704.

46. Janke R, Genzel Y, Wahl A, Reichl U: Measurement of key enzyme activities in mammalian cell lines using rapid and sensitive microplate-based assays. Biotechnol Bioeng 2010, 107(3):566-81.

47. Taschwer M, Hackl M, Hernandez Bort JA, Leitner C, Kumar N, Puc U, Grass J, Papst M, Kunert R, Altmann F, Borth N: Growth, productivity and protein glycosylation in a $\mathrm{CHO}$ EpoFc producer cell line adapted to glutamine-free growth. J Biotechnol 2012, 157(2):295-303.

48. Capiaumont J, Legrand C, Carbonell D, Dousset B, Belleville F, Nabet P: Methods for reducing the ammonia in hybridoma cell cultures. J Biotechnol 1995, 39(1):49-58.

49. Hassell T, Gleave S, Butler M: Growth inhibition in animal cell culture. The effect of lactate and ammonia. App/ Biochem Biotechnol 1991, 30(1):29-41.

50. Fuchs BC, Bode BP: Stressing out over survival: glutamine as an apoptotic modulator. J Surg Res 2006, 131(1):26-40.

51. Niederlechner S, Klawitter J, Baird C, Kallweit AR, Christians U, Wischmeyer PE: Fibronectin-integrin signaling is required for L-glutamine's protection against gut injury. PLoS One 2012, 7(11):e50185.

52. Chen $\mathrm{P}$, Harcum SW: Effects of amino acid additions on ammonium stressed CHO cells. J Biotechnol 2005, 117(3):277-286.

53. Genzel Y, Ritter JB, König S, Alt R, Reichl U: Substitution of glutamine by pyruvate to reduce ammonia formation and growth inhibition of mammalian cells. Biotechnol Prog 2005, 21(1):58-69.

54. Buentemeyer $\mathrm{H}$ : Methods for off-line analysis of nutrients and products in mammalian cell culture. In Methods in Biotechnology. Volume 24. 2nd edition. Edited by Poertner R. New York: Humana Press Inc; 2007:253-268.
55. Stephanopoulos GN, Aristidou AA, Nielsen J: Metabolic Engineering Principles and Methodologies. Orlando: Academic Press; 1998.

56. Ozturk SS, Palsson BO: Chemical decomposition of glutamine in cell culture media: effect of media type, $\mathrm{pH}$, and serum concentration. Biotechnol Prog 1990, 6(2):121-128.

57. van der Heijden RT, Heijnen JJ, Hellinga C, Romein B, Luyben KC: Linear constraint relations in biochemical reaction systems: I. Classification of the calculability and the balanceability of conversion rates. Biotechnol Bioeng 1994, 43(1):3-10.

58. Klamt S, Schuster S, Gilles ED: Calculability analysis in underdetermined metabolic networks illustrated by a model of the central metabolism in purple nonsulfur bacteria. Biotechnol Bioeng 2002, 77(7):734-751.

59. Orth JD, Thiele I, Palsson BO: What is flux balance analysis? Nat Biotechnol 2010, 28(3):245-248.

60. Llaneras F, Pico J: An interval approach for dealing with flux distributions and elementary modes activity patterns. J Theor Biol 2007, 246(2):290-308.

61. Mancuso A, Sharfstein ST, Tucker SN, Clark DS, Blanch HW: Examination of primary metabolic pathways in a murine hybridoma with carbon-13 nuclear magnetic resonance spectroscopy. Biotechnol Bioeng 1994, 44(5):563-585.

doi:10.1186/1472-6750-14-72

Cite this article as: Lohr et al:: The avian cell line AGE1.CR.pIX

characterized by metabolic flux analysis. BMC Biotechnology 2014 14:72.

\section{Submit your next manuscript to BioMed Central and take full advantage of:}

- Convenient online submission

- Thorough peer review

- No space constraints or color figure charges

- Immediate publication on acceptance

- Inclusion in PubMed, CAS, Scopus and Google Scholar

- Research which is freely available for redistribution

Submit your manuscript at www.biomedcentral.com/submit
C Biomed Central 